\title{
Atores Não Estatais e Trade Policy-Making no Brasil: Análise dos Interesses e das Estratégias da CEB e da REBRIP
}

\author{
Ivan Tiago Machado Oliveira ${ }^{1}$
}

Carlos R. S. Milani ${ }^{2}$

${ }^{1}$ Doutor em Administração pela Universidade Federal da Bahia (UFBA) e pesquisador do Instituto de Pesquisa Econômica Aplicada (IPEA). Atualmente coordena projeto de pesquisa sobre a regulação do comércio global. E-mail: ivan.oliveira@ipea.gov.br.

${ }^{2}$ Professor e pesquisador do Instituto de Estudos Sociais e Políticos (IESP) da Universidade do Estado do Rio de Janeiro (UERJ). E-mail: crsmilani@iesp.uerj.br.

\section{INTRODUÇÃO: 0 CONTEXTO, OS CONCEITOS E A LITERATURA SOBRE 0 TEMA}

Dois movimentos-chave transformam a agenda doméstica e a inserção internacional do Brasil entre o final dos anos 1980 e início dos anos 1990: a liberalização política e a abertura econômica. Na análise de Maria Regina Soares de Lima (2000), a confluência entre esses vetores de mudança enseja nova fase da política externa brasileira (PEB), por ela denominada de "integração competitiva". Nessa fase, interesses setoriais de distintos atores não estatais, em função dos efeitos distributivos produzidos pelas decisões de política externa na economia doméstica, passam a ser articulados e contemplados nas agendas da política comercial externa, perturbando o tradicional isolamento do Ministério das Relações Exteriores (MRE) e redefinindo o seu papel no processo de formulação e na condução dessa política (Moura, 2007). Confirma-se, assim, a transitoriedade do interesse nacional, cada vez mais dependente das preferências das forças sociais e dos interesses da coalizão política vencedora, que não apenas podem mudar, como também estão sujeitos a inúmeros conflitos internos (Helen Milner apud Lima, 2000).

Muito embora a noção de autoridade política legítima (authoritativeness) da ação externa do Estado se mantenha fundamental, a existência

DADOS - Revista de Ciências Sociais, Rio de Janeiro, vol. 55, n-2, 2012, pp. 367 a 401. 
de uma pluralidade de atores na redefinição do interesse nacional tende a se constituir, desde os anos 1990, em elemento importante no jogo político da formulação das agendas da PEB. De outros ministérios "domésticos" (Fazenda, Cultura, Educação etc.), agências burocráticas, administrações estaduais e municipais a federações empresariais, movimentos sociais e organizações não governamentais, inúmeros são os atores que logram intervir nas atuais agendas da política externa (Pinheiro e Milani, 2012). Como relatam Sanches Badin e França (2010), há que se considerar, ademais, o adensamento da presença de diversos órgãos da burocracia federal em temas internacionais, que buscam capacitar-se a fim de executarem suas agendas por meio de assessorias internacionais cada vez mais especializadas e robustas. A cena política na qual se desenrola o conflito de interesses e os jogos de poder é, portanto, "povoada de atores sociais de toda espécie" (Badie, 2010:49).

Tem-se, assim, uma paulatina, embora não consolidada, mudança na configuração do campo da PEB, agora compreendida como política pública, que tem o Estado como moderador e legitimador dos interesses mais diversos em um contexto político que amplia a interface entre a agenda doméstica e a internacional. Como afirmou Celso Lafer, em artigo publicado no Estado de S. Paulo, "a política externa é uma política pública. Interessa a todos, pois trata da gestão dos interesses coletivos de uma nação no mundo" (Lafer, 2007:1). Quanto ao caso particular da política comercial externa, considerando seus efeitos distributivos e impactos domésticos, pode-se caracterizá-la ainda mais claramente enquanto política pública e, portanto, sujeita à avaliação, demanda de transparência e escrutínio público. Estudar a política externa enquanto política pública implica buscar teórica e metodologicamente "entender como e por que os governos optam por determinadas ações" (Souza, 2006:22), dando-lhe a prerrogativa de mudança e transitoriedade de acordo com a lógica resultante das disputas de interesses no jogo político ${ }^{1}$.

Porém, lembrando Pinheiro (2009), a crescente participação de atores não estatais na arena de formulação da política externa no Brasil não os coloca como definidores em última instância das ações de política externa a serem implementadas. Os atores não estatais, sejam as organizações empresariais, sejam os movimentos e redes de ativismo político, não podem ser considerados tomadores de decisão em política externa, muito embora tenham capacidade de articulação de interesses e de influência, ou seja, são dotados de forte poder de agência. A atuação 
desses atores amplia a contribuição propriamente política dos atores da sociedade para a estruturação da política externa do país. Lima e Santos (2001), ao analisarem a relação entre o Legislativo e o Executivo no Brasil contemporâneo em torno de temas de política externa e comércio exterior, apontam para a consagração do Executivo enquanto agente definidor de última instância, atuação que estaria vinculada a uma política iniciada com o golpe militar de 1964, que concentrou poder em torno do presidente, e que tenderia a resistir à agenda de democratização da política externa.

Esse paradoxo que se constrói em torno da política externa, concomitantemente política de Estado (no sentido de sua continuidade) e política pública (seguindo as orientações do governo), seria, no entanto, apenas aparente. Haveria sempre algo de permanente na política externa (por exemplo, o respeito ao princípio de não intervenção, a solução pacífica das controvérsias entre os Estados, a defesa do direito internacional público, entre outros fundamentos constitucionais das relações internacionais do Brasil) ${ }^{2}$, porém também ocorrem variações em suas agendas, de acordo com as interpretações e preferências da coalizão no governo e as contingências (domésticas e externas) do exercício do poder (Amorim Neto, 2011; Lopes, 2011; Pinheiro e Milani, 2012). A PEB não é imutável e pode sofrer mudanças em suas agendas e em seus atores por motivos sistêmicos e de acordo com as agendas dos governos. Como argumenta Amorim Neto (2011), a presidencialização da diplomacia brasileira tende a despartidarizar o cargo de Ministro das Relações Exteriores, mas ao mesmo tempo a politiza, no sentido de colocá-la no jogo político doméstico dos interesses e das preferências. Ou seja, o diplomata e o soldado de Raymond Aron têm de se acostumar com a companhia, embora por vezes tímida e nem sempre assídua, de burocratas do setor da saúde (ou da cultura, da educação, do desenvolvimento agrário etc.), de deputados e senadores (e seus assessores legislativos), prefeitos e governadores, operadores econômicos, líderes de ONGs, movimentos sociais, organismos da mídia e personalidades da academia (Milani, 2012).

No seio do Itamaraty, observaram-se algumas aberturas em direção à sociedade ao longo das últimas décadas. Nos anos 1990, foram estabelecidos o Comitê Empresarial Permanente do MRE, o Fórum Consultivo Econômico e Social do Mercosul, a Seção Nacional de Consulta sobre a União Europeia e o Grupo Interministerial de Trabalho sobre Comércio Internacional de Mercadorias e de Serviços (Lopes, 2011). No 
documento de orientação estratégica do Ministério das Relações Exteriores no Plano Plurianual 2008-2011, o diálogo com a sociedade em geral sobre a agenda de política externa é apresentado positivamente:

A agenda diplomática tem-se tornado a cada dia mais complexa. Temas como as negociações comerciais multilaterais, os direitos humanos, o meio ambiente, o desenvolvimento sustentável, o combate à fome e à pobreza, entre outros, afetam cada vez mais a vida do cidadão. É fundamental, portanto, que a política externa esteja sintonizada com os anseios da sociedade. O diálogo com os movimentos sociais, a imprensa, o Congresso Nacional e as unidades da Federação contribui para tornar a ação do Ministério das Relações Exteriores mais representativa das aspirações nacionais (Brasil, 2007:26, ênfase nossa).

O próprio ex-ministro das Relações Exteriores, Celso Amorim, passou a reiterar publicamente a visão da política externa como política pública, embora com viés reducionista quanto a suas características e a sua avaliação, vinculando-a apenas ao escrutínio público eleitoral. “(...) $a$ política externa é uma política pública como as demais. Está sujeita à expressão das urnas e da opinião pública. Os princípios são os mesmos, mas as prioridades e agendas podem mudar" (Amorim, 2010:13).

Não obstante a permanência da centralidade do Poder Executivo, particularmente do Itamaraty, na formulação da agenda de política externa brasileira, há que se lembrar que a pluralidade de atores sensíveis às negociações internacionais, como ressaltam Oliveira, Onuki e Veiga (2006). No que diz respeito à arena comercial mais particularmente, Veiga (2002) chamou a atenção para o processo de expansão do leque de novos atores não estatais, fortemente capazes de influenciar a política brasileira: segundo o autor, atores tradicionais (a exemplo das associações empresariais setoriais) continuam a ser importantes interlocutores do governo no campo comercial, mas emergem novas entidades da sociedade civil organizada que tendem a assumir papéis cada vez mais significativos, especialmente nos mecanismos de consultas para negociações comerciais. A marca da atuação desses atores não estatais estaria, para Veiga (2002), em seu perfil de interesses orientados a múltiplos setores e em sua relativa independência frente às posições governamentais.

Nesse campo da política comercial, considerado de relevo no seio da política externa graças às características socioeconômicas e à inserção econômica do Brasil no cenário internacional, a abertura das institui- 
ções ao diálogo com atores não estatais foi realizada a partir de meados da década de 1990, tendo nas negociações para a formação da Área de Livre Comércio das Américas (Alca) seu momento catalisador. De acordo com Veiga (2007a), no plano das negociações comerciais, a Alca é o fator que está na origem de uma ampla reorganização do processo de negociação e de consultas domésticas. O Fórum Empresarial das Américas, instituído em 1995 para ser o espaço de avaliação e debate por partes dos empresários sobre as negociações levadas a cabo pelos governos para a realização a Alca, foi uma das primeiras iniciativas de abertura institucionalmente organizada da agenda de negociações ao setor empresarial. Contudo, como relatam Santana (2001) e Carvalho (2003), a composição da participação no Fórum dependia do convite feito pelo MRE (participação por convite), que muitas vezes desconsiderava a representatividade (ou a sua falta) do empresariado convidado.

Em 1996, foi estruturada no Brasil a Seção Nacional de Coordenação dos Assuntos Relacionados à Área de Livre Comércio das Américas (Senalca), sob a coordenação do Itamaraty. A Senalca tinha o objetivo de servir como foro de debate de temas na agenda de negociações comerciais hemisféricas que auxiliaria na definição da posição do Brasil na Alca. Além de integrar representantes de diversos ministérios, inclusive da Câmara do Comércio Exterior (Camex) e do Ministério do Desenvolvimento, Indústria e Comércio Exterior (MDIC), a Senalca tinha autorização para convidar à participação em suas discussões as entidades representativas do empresariado, de sindicatos e da sociedade civil organizada. Como destaca Veiga (2007a), os atores não estatais participavam das reuniões na condição de observadores convidados pelo governo. Assim, as discussões eram pautadas e limitadas pelo Itamaraty por meio dos coordenadores do foro, não restando margem importante de debate além daquela definida pelos atores institucionais. De toda forma, a Senalca representou passo importante na institucionalização do processo direcionado de consultas à sociedade sobre temas da agenda de política comercial externa no Brasil.

Durante as negociações da Alca, também foram criados Grupos de Trabalho Interministeriais, responsáveis pelo acompanhamento das negociações de cada grupo de negociação do acordo para a formação da Alca. Nesses Grupos Interministeriais, atores não estatais eram eventualmente consultados e convidados à participação de suas reuniões, ainda que informalmente (Santana, 2001; Veiga, 2007a). Configurou- 
se, assim, um modelo de consultas baseado em dois eixos: a Senalca, mais institucional, e os Grupos Interministeriais, com consultas informais.

Esse modelo de aproximação da agenda de negociação comercial do Brasil de atores não estatais serviu de base para a criação da Seção Nacional de Coordenação dos Assuntos Relacionados à Associação InterRegional Mercosul-União Europeia (Seneuropa) em 2001. De fato, a lentidão no estabelecimento da Seneuropa parece ter vínculos com a relutância europeia na aproximação do empresariado com a agenda de negociações. No seio da Seneuropa, passou-se a envolver representantes da Comissão Parlamentar Conjunta e do Fórum Consultivo Econômico e Social do Mercosul, criado pelo Protocolo de Ouro Preto, em 1994, como órgão de representação dos setores econômicos e sociais. Cabe sublinhar que a dinâmica encontrada nas negociações da Alca, pautada no convite feito pelo Executivo ao setor privado para participar de reuniões oficiais na sala ao lado, como apresentado por Santana (2001), não foi replicada com êxito nas negociações entre o Mercosul e a UE.

Quando se iniciaram tratativas no âmbito da Organização Mundial do Comércio (OMC) para o lançamento de uma nova rodada multilateral de negociações comerciais em 1998, o governo brasileiro, por meio do MRE, passou a se preocupar com a sua capacidade de articulação de interesses e mesmo de uma definição clara das preferências na formulação das posições negociadoras do Brasil. Além de reformulações burocráticas no Itamaraty, particularmente no Departamento Econômico, buscou-se ampliar o leque de contatos e elos entre o setor privado e o governo, e inclusive entre as burocracias estatais a fim de se montar uma estrutura de diálogo que permitisse ao país ter posições definidas no caso do lançamento da Rodada do Milênio. Foi no bojo desse processo que se criou, em 1999, o Grupo de Trabalho sobre Comércio Internacional de Mercadorias e de Serviços (GICI).

O GICI foi apresentado como o núcleo de coordenação e formulação de posições brasileiras sobre temas e agendas de negociações conduzidas no âmbito da OMC. O grupo ficou responsável pela discussão interna dos temas relevantes para o desenvolvimento nacional, em sua interface com o comércio internacional, particularmente no que diz respeito ao regime multilateral. Como analisa Carvalho (2003), a relação do GICI com a sociedade civil não foi definida a priori, cabendo ao grupo 
promover o diálogo sempre que considerado oportuno. A participação de atores não estatais tanto empresariais e sindicais quanto da sociedade civil organizada dependeria, portanto, de convite oficial, seguindo o modelo aplicado na Senalca. O GICI cumpriria também a função de dar maior transparência e ampliar o acesso à informação sobre as negociações comerciais na OMC. Contudo, de acordo com a análise de Carvalho (2003) sobre a participação do setor privado no GICI, a centralização da agenda em mãos do MRE e a participação relativamente sob controle limitaram sua importância enquanto foro de consultas, dando ao grupo uma função essencialmente simbólica, de legitimação de uma posição oficial pré-definida. De toda forma, o GICI deve ser visto como um mecanismo criado no bojo de mudanças no processo de formulação da política comercial externa do Brasil e que apresenta potencial de estímulo ao diálogo entre setores do Estado e da sociedade na construção de posicionamentos negociadores do país no âmbito multilateral.

Como se pode observar, atores empresariais e da sociedade civil organizada puderam atuar em defesa de seus interesses com vistas a influenciar a formulação das estratégias de negociação comercial do Brasil, utilizando-se dos mecanismos de consultas criados ao longo da década de 1990, ainda que limitados e direcionados. Para se compreender a dinâmica da interação entre atores estatais e não estatais na definição de prioridades na estratégia de negociação comercial posta em prática pelo Brasil nas últimas décadas, cabe analisar os interesses que estruturam as preferências dos atores não estatais em questão e seus efeitos sobre sua atuação.

No caso brasileiro, dois atores não estatais são particularmente importantes pela sua capacidade de ação e pela articulação desenvolvida nos foros de consultas e negociações criados pelo Itamaraty, quais sejam: a Coalizão Empresarial Brasileira (CEB), que congrega setores empresariais múltiplos e com interesses diversificados; e a Rede Brasileira pela Integração dos Povos (Rebrip), coordenadora de interesses e ações comuns de sindicatos, movimentos sociais e de organizações da sociedade civil organizada no campo das negociações comerciais internacionais.

$\mathrm{Na}$ literatura nacional e internacional não são muito frequentes os estudos sobre políticas comerciais que envolvam a análise de interesses e da participação de atores não estatais em sua formulação. O estudo coordenado por Capling e Low (2010) apresenta a primeira sistematiza- 
ção sobre a participação de atores não estatais na formulação de políticas comerciais no que concerne à escolha do fórum de negociação (multilateral ou regional/preferencial) para um grupo de países selecionados, entre os quais não se encontra o Brasil. De toda forma, da leitura atenta do estudo, conclui-se que a ampliação da participação de múltiplos atores na agenda da política comercial é um fenômeno que transcende fronteiras, destacando-se tanto em países mais desenvolvidos quanto nos menos desenvolvidos, com características distintas que refletem momentos históricos e políticos nos diversos países analisados.

Como sumarizado em Capling e Low (2010), ao analisarem os fatores intervenientes na escolha do fórum, a preferência por estratégias negociadoras com foco em acordos regionais de comércio pode estar vinculada a objetivos de política comercial que visam a: a) proteger da competição externa com ampliação da base geográfica de um processo de substituição de importações; b) realizar acordos menores em escopo e profundidade como um laboratório para a adaptação e reforma das economias envolvidas, com transbordamento do aprendizado para negociações multilaterais; c) consolidar objetivos estratégicos e políticos em âmbito regional, desvinculados de uma agenda puramente comercial e com vínculos multilaterais; e d) aumentar o poder de barganha dos países signatários de um acordo regional, consolidando a cooperação entre eles e ampliação de suas capacidades de negociação em âmbito multilateral.

As negociações multilaterais de comércio também podem ser vistas como menos eficientes quando se buscam negociações com velocidade aumentada e num grupo menos heterogêneo e amplo de países. Para Capling e Low (2010), outros fatores importantes na escolha do fórum seriam os seguintes: a ausência de uma temática específica na agenda multilateral; a redução da incerteza, observada como maior e mais clara nos acordos regionais principalmente pelas grandes potências comerciais; o medo da exclusão; a perda de margens de preferência que um país pode ter com outro devido à assinatura de um acordo entre o último e um terceiro país.

O trabalho organizado por Capling e Low (2010) destaca, como síntese dos estudos de caso apresentados, que parece haver uma convicção de que a OMC é muito remota e muito grande para que os atores não estatais consigam atingir seus objetivos quanto à formulação de política 
comercial externa. Ademais, o efeito da liberação comercial ocorrida por meio de acordos regionais de comércio é mais rápido e em muitos casos mais profundo daqueles observados como resultados de negociações multilaterais de comércio. O estudo dá pouca atenção, contudo, a atores não estatais de contestação e negação da lógica que envolve os acordos comerciais, como a Rede Brasileira pela Integração dos Povos (Rebrip) no Brasil, dando foco naqueles que coadunam interesses privados empresariais e sindicais.

Nas últimas décadas, vários países começaram a estabelecer mecanismos desenhados para facilitar maior acesso à informação sobre política comercial e promover diálogo e interação entre atores estatais e não estatais. Dentre os estudos que descrevem os mecanismos de consultas à sociedade civil organizada e a grupos empresariais criados por diversos países no campo da política comercial externa, cabe destacar Intal (2002), Hocking (2004), Gallagner, Low e Stoler (2006), Veiga (2007b) e Capling e Low (2010). A análise dos resultados dos estudos citados indica que a maioria dos mecanismos de consultas à sociedade, tanto formais quanto informais, surgiu ao longo de processo de negociação de acordos regionais e não de negociações multilaterais e privilegia atores empresariais, mais organizados e com melhores recursos e capacidade de participação, em detrimento de atores da sociedade civil organizada. Identifica-se também que os países em desenvolvimento são menos transparentes quanto a informações sobre política comercial do que os países desenvolvidos, o que inibe a participação e o engajamento de atores não estatais.

Em diversos estudos, como em Intal (2002), em Wolfe e Helmer (2007) e em Capling e Low (2010), encontra-se uma avaliação positiva acerca da necessidade de se ampliarem a transparência e a participação na formulação de políticas comerciais, a fim de aumentar a legitimidade dessa política e incrementar a coesão social e apoio ampliado à liberalização. Eles não consideram, contudo, que, a depender da economia política e da lógica de poder domésticas que envolvem a política comercial externa de um país, pode-se estar reduzindo o impulso liberalizante a fim de garantir a coesão social e dar maior legitimidade à política. Pode-ser observar, pois, que a transferência e ampliação da participação são elementos positivos, mas não determinam a política comercial numa única direção, a da liberalização. Os caminhos resultantes da interação entre atores estatais e não estatais na formulação da política comercial externa são múltiplos, e muitas vezes duais, e resultam da co- 
ordenação de vetores de interesse e poder num dado período político e histórico de um país.

Nos estudos realizados por Lima (1990; 2000; 2005) e Lima e Santos (2001), encontram-se análises sobre a democratização das agendas de política externa no Brasil, tendo a agenda comercial um papel destacado nos estudos. Lima (1990) apresenta estudo pioneiro na análise da economia política da política externa, colocando a política comercial como um de seus três elementos de análise. A relação entre o Legislativo e o Executivo na formulação da política de comércio exterior é o foco do trabalho de Lima e Santos (2001), que questionam a centralidade e concentração de poder no segundo em detrimento do primeiro para elucidar o debate sobre a democratização da agenda de política externa no Brasil.

Santana (2001) analisa a participação de grupos de interesse nas negociações para a formação da Alca, considerando a relação entre o setor empresarial e o sindical com os "operadores diplomáticos", no processo de formação da posição brasileira nas negociações. O autor tem foco na construção dos canais de diálogo e aproximação entre atores domésticos na formação de posicionamento dos negociadores no acordo regional específico.

Veiga (2007a) analisa a política comercial brasileira e apresenta os principais atores não estatais envolvidos na sua formulação, ou na tentativa de influenciá-la, a CEB e a Rebrip. Mas sua análise tem foco na descrição de suas ações nos comitês e fóruns de consulta criados pelo Estado nos últimos anos. Não há uma análise de como seus interesses e estratégias de atuação se refletem em preferências na definição do fórum negociador por parte da política comercial externa brasileira.

A diversidade da agenda comercial brasileira com a atuação de novos atores em seu processo de formulação é destacada por Veiga (2007b). O autor identifica ainda que coalizões protecionistas em âmbito doméstico, que costumavam dominar o processo no Brasil, passaram a ter concorrência importante e foram substituídas por organizações empresariais com interesses exportadores e mais liberais. Veiga (2007b) relata também a defesa de um protecionismo com causas sociais por atores não estatais da sociedade civil organizada e a ampliação de atores estatais que participam de ações no campo da formulação de política comercial. Contudo, o autor não considera a relação entre interesses e sua vinculação à lógica negociadora nos distintos fóruns às oportunidades 
de negócios e de comércio que os acordos regionais trazem do que àquelas relacionados à abertura pela via multilateral.

Carvalho (2003) analisa a formação da posição brasileira para as negociações de lançamento da Rodada do Milênio em Seattle em 1999, tomando por base a formação de grupos de interesses. Em sua análise, a autora destaca a agenda empresarial e dos trabalhadores organizados, além de identificar as preferências do governo nos mecanismos criados para a interação com a sociedade civil organizada. O estudo tem, assim, foco na agenda que seria apresentada na reunião ministerial da $\mathrm{OMC}$ em Seattle, não considerando as preferências e interação entre atores não estatais quanto a acordos regionais, nem aprofundando a análise dos condicionantes das preferências do governo.

Ao analisar a formação do G20 agrícola na OMC, Carvalho (2010) busca definir elementos da agenda multilateral e da realidade econômica e política doméstica que teriam influência na conformação de uma posição do Brasil frente às negociações agrícolas na OMC. Aqui também foram destacados os mecanismos de participação criados pelo governo, como o grupo de técnico informal sobre agricultura, que inclui representantes de ministérios e de organizações empresariais e da sociedade civil organizada na área de agricultura. $O$ vetor resultante da coordenação doméstica de interesse defensivos, fundamentalmente da agricultura familiar que insiste na manutenção de programas de auxílio ao produtor, e ofensivos, do grande empresariado do agronegócio, foi determinante para a definição de uma posição do Brasil no quadro do G20.

Os estudos existentes no campo da análise da política comercial em geral não envolvem o exame da interação entre seus múltiplos determinantes domésticos, tomando como foco as preferências e formas de atuação de atores não estatais com os estatais. Ademais, trabalhos com foco na pluralidade de atores e interesses que atuam para influenciar a nova agenda de comércio dos países são raros, particularmente sobre a experiência brasileira (Abreu, 2007; Oliveira, Onuki e Veiga, 2006; Veiga, 2007a). Assim, com o presente trabalho busca-se preencher uma lacuna na literatura nacional e internacional sobre a análise da política comercial externa do Brasil quando se considera de forma integrada o conjunto dos elementos domésticos, em particular ações e posições estratégicas dos principais atores não estatais envolvidos na economia política da política externa comercial brasileira. 
Assim, o presente artigo procurará analisar como os atores empresariais, articulados em torno da CEB, e atores da sociedade civil organiza$\mathrm{da}$, por meio da Rebrip, atuaram em defesa de seus interesses, visando a influenciar a formulação das estratégias de negociação comercial do Brasil. Além disso, o artigo visa a compreender em que medida essa atuação foi importante para a definição de prioridades negociadoras. Para tanto, toma-se como premissa que a política comercial externa do Brasil fez uso de uma estratégia de negociação em três trilhos nos últimos quinze anos, com a prioridade às negociações no âmbito do regime multilateral de comércio (primeiro trilho), combinada com um regionalismo em dois tempos, um de ampliação e aprofundamento da integração regional na América do Sul (segundo trilho) e outro de negociação de acordos regionais fora da região (terceiro trilho). Tendo como ponto de partida tal premissa, e com base em metodologia qualitativa (análise de conteúdo de documentos oficiais e artigos publicados em jornais de circulação nacional, entrevistas semiestruturadas com representantes de ambos os setores e do Ministério das Relações Exteriores), analisam-se nas seções seguintes as preferências e a atuação da CEB e da Rebrip enquanto atores não estatais relevantes para a análise e compreensão da política comercial externa brasileira contemporânea.

\section{PREFERÊNCIAS E ATUAÇÃO DA COALIZÃO EMPRESARIAL BRASILEIRA}

A CEB foi criada em 1996 e reúne associações dos setores agrícola, industrial e de serviços no Brasil. A criação da CEB se deu de forma fundamentalmente reativa e tendo as negociações da Alca como fator impulsionador. Segundo relato de representante do setor privado que coordenou a área de negociações comerciais da CEB, somente após a II Reunião Ministerial sobre Comércio para a formação da Alca, em Cartagena em 1996, o setor privado brasileiro se deu conta do que estava acontecendo no âmbito das negociações comerciais hemisféricas. A criação da secretaria executiva da Alca deu ao processo negociador maior rapidez, o que gerou pressão sobre os setores empresariais brasileiros para se organizarem mais celeremente. A secretaria levou ao avanço nas negociações técnicas, que seguiram rapidamente à frente dos acordos políticos. Como se pode analisar, as negociações da Alca foram uma escola única para o setor privado brasileiro, representando um divisor de águas em termos de preparação e de profissionalização do setor empresarial para as negociações internacionais, e a formatação da CEB representa o início desse processo. 
Observa-se que não havia amplo acesso a informações nem participação coordenada e efetiva do setor empresarial brasileiro nas negociações internacionais realizadas pelo Brasil até então. Pouco se sabia o que se estava negociando e os impactos potenciais ou reais sobre os setores econômicos na pauta de negociação. A criação da CEB simbolizou um novo momento para o setor privado no que concerne à atuação em defesa de seus interesses no campo da formulação de estratégias negociadoras da política comercial brasileira. Assim, a CEB representou o despertar reativo e essencialmente defensivo dos setores empresariais brasileiros para o mundo das negociações comerciais, estruturando atividades e posições do setor privado que eram encaminhadas no âmbito dos novos mecanismos de consulta e participação de atores não estatais para os tomadores de decisão de última instância da política externa brasileira, isto é, o Itamaraty e a Presidência da República.

Ao analisar a novidade que a CEB encerra, Veiga (2007a) destaca o rompimento da tradição setorialista de representação do empresariado no Brasil. Segundo o autor:

A CEB é uma novidade institucional, não somente porque agrupa em bases voluntárias diferentes setores e age como foro de negociações diretas e formação de consenso entre esses setores - rompendo a tradição setorial na representação e no processo de fortalecimento de interesses que constitui um traço marcante do setor empresarial no Brasil -, mas também porque se trata de uma organização empresarial dedicada a um só tema: negociações comerciais (Veiga, 2007a:132).

Uma posição gradualista com redução do ritmo negociador para a formação da Alca, em consonância com os interesses do governo, foi articulada nas diversas entidades que compõem a CEB e apresentada na III Reunião Ministerial, em Belo Horizonte, em 1997. Para Santana (2001), o apoio da CEB à posição gradualista nas negociações da Alca, como defendida pelo MRE, tem bases instrumentais relacionadas às pressões domésticas do setor privado pela conclusão das reformas estruturais que reduziriam o "custo Brasil". A CEB alinhava-se ao Itamaraty no plano externo a fim de barganhar posições que atendessem aos seus interesses no plano doméstico.

Desde a sua criação em 1996, a CEB acompanhou de perto as negociações da Alca e participou como entidade convidada da Senalca, expondo e defendendo as preferências e os interesses do setor privado brasileiro frente às negociações. Essa participação colocou o empresariado 
em diálogo direto com os principais atores da política comercial externa brasileira durante processo negociador da Alca, ampliando a legitimidade da própria política, que passou a refletir de forma mais explícita e embasada os condicionantes advindos da economia política doméstica em profunda transformação. Um elemento de destaque durante tais negociações diz respeito à aproximação da agenda patronal com a dos sindicatos. A manutenção da proteção e dos lucros dos empresários significava a existência do emprego, particularmente o industrial, defendido pelos sindicatos.

Na Reunião Ministerial de Miami, em novembro de 2003, definiu-se uma nova visão para as negociações do acordo da Alca, que passavam a ser estruturadas em três conceitos: equilíbrio, abrangência e flexibilidade. Após a redefinição dos pilares negociadores, a CEB apresentou de forma mais contundente o objetivo do empresariado em relação à Alca, baseado fundamentalmente em ganhos com a ampliação de exportações para novos mercados. Como salienta um documento de posicionamento da Coalizão sobre as negociações da Alca:

(...) o principal objetivo do empresariado brasileiro nas negociações, qual seja, a obtenção de ganhos concretos em termos de acesso a mercados para a exportação de seus produtos e serviços. Na visão dos empresários brasileiros, é possível perseguir de forma persistente este objetivo prioritário sem comprometer a capacidade do país para implementar políticas industriais (CEB, 2004:01-02, ênfase nossa).

A dinâmica de participação de atores não estatais seguida na Alca foi levada às negociações entre o Mercosul e a União Europeia para a formação de uma área de livre comércio. Na Seneuropa, o setor privado continuou a encontrar caminhos de interação em defesa de seus interesses e visões sobre a participação do Brasil em acordos comerciais internacionais. Com os ganhos potenciais mais concentrados no setor agrícola brasileiro nesse acordo Mercosul-UE, a CEB manteve posição flexível que sinalizava para a barganha entre setores, mas que consideraria aspectos atinentes à assimetria econômica, particularmente no setor industrial, entre os dois blocos. A preocupação com as assimetrias econômicas e a importância de se levar uma agenda de tratamento diferenciado aos países em desenvolvimento pode ser vista no seguinte excerto da Declaração de Madri do Fórum Empresarial Mercosul-União Europeia (MEBF) de 2002, assinada pela CEB: 
(...) Com o objetivo de reduzir a distância em termos de desenvolvimento econômico entre os países membros da União Europeia e do Mercosul, a MEBF recomenda que as negociações entre os dois blocos promovam mecanismos de tratamento especial e diferencial. Esses mecanismos devem incluir listas mais amplas de produtos sensíveis com períodos de liberalização mais longos, uma via mais lenta para a eliminação de tarifas e períodos de carência mais longos, entre outras provisões que poderiam diminuir os custos de ajuste para os países membros do Mercosul (CEB, 2002:9, ênfase nossa; tradução do editor).

Segundo representante da CEB, a agenda de negociações da Alca, em geral, interessava mais aos setores organizados na Coalizão do que a que norteava as negociações entre o Mercosul e a UE. O potencial ganho em termos de acesso a mercados em alguns setores industriais nos Estados Unidos com a Alca e as expectativas de ganho concentrado no setor agrícola com o acordo Mercosul-UE embasavam o interesse mais ampliado no primeiro relativamente ao segundo. Como se observa, os interesses do setor privado nem sempre seguiam caminhos convergentes para a consolidação de uma posição consensual. Por vezes, posicionamentos defensivos e ofensivos eram debatidos no âmbito da CEB, que apresentava ao governo, nos comitês de consulta, os pontos consensuais e os dissensos da agenda de negociação, cabendo ao MRE arbitrar sobre que posição tomar diante de interesses setoriais irreconciliáveis. Na análise de Veiga (2007a): “(...) a ALCA era o primeiro processo de negociação que simultaneamente atraía a atenção dos dois tipos de setor: o que concorria com as importações, por razões defensivas, e o dos exportadores, por razões de natureza ofensiva" (Veiga, 2007a:134).

Vale lembrar que muitos setores industriais presentes na CEB têm interesses especiais na integração da América do Sul, importante trilho da estratégia comercial brasileira. Alguns dos setores mais fechados da economia brasileira, a exemplo do setor automobilístico, vêm ganhando com o processo de integração econômico-comercial na região. Como em geral a indústria brasileira é a mais competitiva da América do Sul, a concorrência não é temida. A CEB destaca em seu posicionamento positivo quanto à integração regional a importância de aprofundar acordos comerciais a fim de que o Brasil não perca margem de preferência tarifária com os acordos celebrados entre os países da região e outros de fora dela, particularmente a China. De acordo com relato de representantes da Coalizão, o medo de triangulação é enorme 
nos acordos comerciais existentes com países da América do Sul. O efeito China sobre os acordos regionais existentes com os países da região reforçaria a necessidade de melhorar os acordos sobre regras de origem e de facilitação de comércio, aumentando o poder da aduana no Brasil a fim de impedir que regras dos acordos existentes fossem desconsideradas em detrimento de interesses de setores econômicos brasileiros.

Em outros acordos regionais de comércio, particularmente aqueles assinados com países em desenvolvimento de fora da América do Sul desde 2003, não houve a formalização da participação de atores não estatais. O escopo reduzido desses acordos pode justificar a falta desses mecanismos, mas a falta de informações sobre o que estava sendo negociado e a personalização das relações entre o Estado e o setor privado foi alvo de críticas de representantes desse setor. A CEB critica o reduzido conteúdo econômico-comercial dos acordos firmados com países em desenvolvimento durante o governo Lula, que teria vinculado a estratégia de negociações de acordos regionais à lógica meramente política, deixando de lado os objetivos econômicos dos acordos regionais de comércio.

Para Veiga (2007a e 2007b), a posição defendida pela CEB nos processos de negociação de acordos regionais fundamentou-se em duas bases: a) na defesa do reconhecimento da reciprocidade assimétrica nos esquemas de liberalização de comércio de bens, particularmente na Alca e nas negociações entre o Mercosul e a UE, a fim de contemplar as diferenças entre níveis de desenvolvimento dos respectivos países; e b) na reprodução dos compromissos assumidos nos acordos comerciais ao final da Rodada Uruguai para temas que envolvam serviços, investimentos, propriedade intelectual, compras governamentais, entre outros.

Observa-se, pois, que a posição do setor privado brasileiro se estruturou em dois pilares que sinalizam para a ideia de que o preço da abertura, pago na Rodada Uruguai por alguns setores empresariais brasileiros, representaria o teto aceitável para muitos temas da agenda comercial e que a condição de país em desenvolvimento deveria dar ao Brasil, à semelhança das regras existentes no regime multilateral de comércio, um tratamento especial e diferenciado quanto aos prazos de liberalização tarifária, especialmente em setores sensíveis, mais vulneráveis à concorrência com importações. Como reitera Veiga (2007a): “A 
participação do setor empresarial nas negociações de comércio focalizou principalmente os temas relativos à proteção do mercado interno e conferiu prioridade à necessidade de moderar quaisquer novas iniciativas de liberalização do comércio - seja regional, seja multilateral" (Veiga, 2007a:132).

No âmbito multilateral, a CEB acompanha as negociações na OMC e, no plano doméstico, participa do GICI. Em seus documentos de posicionamento político-negociador encontra-se referência à importância do regime multilateral de comércio para um país em desenvolvimento como o Brasil. Quando da tentativa de lançamento da Rodada do Milênio em Seattle (em 1999), a Coalizão Empresarial Brasileira manifestou posição defensiva quanto a se negociar redução tarifária para bens industriais, considerando que o atual padrão de proteção industrial estaria adequado. Segundo a CEB (1999):

A maioria dos setores industriais brasileiros manifestou posição contrária à negociação de tarifas industriais na OMC. As tarifas praticadas atualmente pelos países desenvolvidos não constituem obstáculo relevante para a expansão das exportações brasileiras de produtos industriais. O impacto sobre o setor industrial brasileiro das reduções tarifárias, que seriam naturalmente exigidas como contrapartida no processo de negociação, superaria largamente qualquer expectativa de ganho nessa área (CEB, 1999:4).

A preocupação protecionista manifestada em Seattle foi também levantada nas negociações comerciais entre o Mercosul e a UE e no início das negociações comerciais na Rodada Doha (em 2001). A visão de que os custos do ajuste aos acordos da Rodada Uruguai teriam sido altos para importantes setores da indústria brasileira pautou a posição da $\mathrm{CEB}$, relativamente à agenda a ser negociada em Doha. No excerto do documento de posicionamento da CEB, que segue, sobre a Rodada Doha, a Coalizão retoma a retórica política de sinalizar para as assimetrias econômicas, que teriam sido ampliadas ao final da rodada anterior. Como relata a CEB (2001):

Ao mesmo tempo que reconhece que o Brasil tem grande interesse em uma nova Rodada de negociações multilaterais, entende a Coalizão Empresarial Brasileira que esta deve levar em consideração as lições da implementação da Rodada Uruguai, especialmente para os países em desenvolvimento. Há hoje consenso de que a implementação desigual dos resultados da Rodada gerou novas assimetrias entre países desenvolvidos e em 
desenvolvimento. A Coalizão Empresarial Brasileira considera, portanto, ser importante reconhecer a necessidade de revisão de acordos que possam estar contribuindo para gerar novas assimetrias entre países com distintos graus de desenvolvimento (CEB, 2001:2, ênfase nossa).

A busca por manter a proteção consolidada e minimizar danos aos interesses empresariais brasileiros advindos de novos acordos comerciais multilaterais leva a CEB a reforçar, em 2005, a importância de mecanismos de tratamento especial e diferenciado a países em desenvolvimento, que deveriam estar presentes nos acordos em negociação na Rodada Doha da OMC. Na negociação multilateral, tanto setores exportadores com posições ofensivas quanto setores competidores de importações com posições defensivas encontram elementos que estruturam suas posições e acomodam interesses em confluência com o próprio marco mais geral da política comercial externa do período.

A Coalizão Empresarial Brasileira (CEB) entende que fortalecer a OMC (Organização Mundial do Comércio) é crucial para a defesa dos interesses do Brasil no que diz respeito ao comércio exterior. O sucesso da Rodada de Doha é essencial para evitar o enfraquecimento do sistema de comércio multilateral e limitar as distorções comerciais geradas por iniciativas regionais. A CEB também acredita que as negociações da Rodada Doha devem ser capazes de produzir resultados significativos em áreas onde os países em desenvolvimento concentram seus interesses em termos de exigências. Ao fazer isso, a Rodada terá dado uma contribuição real aos esforços empreendidos por esses países na direção do desenvolvimento. O mandato de Doha determina a inclusão dos princípios de tratamento especial e diferencial para países em desenvolvimento e reciprocidade parcial nas concessões a serem negociadas no tocante ao acesso ao mercado para produtos industriais. A combinação desses dois princípios deveria refletir-se em compromissos menores em termos de redução de tarifas, com períodos mais longos para implentação e a possibilidade de manutenção da porcentagem de linhas tarifárias com cortes menores do que previstos nas fórmulas, ou até mesmo isentas de liberalização (CEB, 2005:1, ênfases nossas; tradução do editor).

Como se observa, segundo interesses consolidados na articulação política da CEB, as negociações para a criação de novas regras para o comércio internacional em suas múltiplas agendas (bens, serviços, investimentos, propriedade intelectual, compras governamentais etc.) deveriam ter como prioridade o fórum multilateral encontrado na OMC. A relevância do sistema de solução de controvérsias da OMC também é 
ressaltada em documentos da CEB, que o avaliam como essencial para o aumento da credibilidade e da estabilidade da regulação do comércio em âmbito global. Assim, o trilho multilateral da estratégia de negociação comercial executada pelo Brasil entre 1995 e 2010 foi vetor preferencial de negociação segundo interesses do setor privado articulado na $\mathrm{CEB}$, coadunando-se à visão oficial referenciada no Itamaraty que conferiu prioridade à participação do país no regime comercial multilateral. Desde julho de 2008, quando a última importante tentativa visando à conclusão da Rodada Doha fracassou, a CEB não tem acompanhado as negociações na OMC.

$\mathrm{Na}$ análise documental, identificou-se que os interesses de setores empresariais brasileiros, particularmente daqueles mais protegidos, em escolher o multilateralismo comercial como prioritário no quadro de suas preferências negociadoras encontram-se relacionados à própria dinâmica do processo de negociação e de adaptação dos acordos realizados nesse fórum. Nas negociações multilaterais, o processo negociador é mais complexo e demorado por envolver uma agenda mais extensa de temas comerciais e um maior número de países, integrando também barganhas cruzadas e formação de coalizões. Ademais, os efeitos da liberalização comercial ou ajustamento a novas regras acordadas no âmbito do regime multilateral de comércio são mais lentos, com dilatação temporal especialmente para países em desenvolvimento. Com isso, os setores que demandam proteção, fundamentalmente concorrentes com importações, preservam-na por um período de transição prolongado, o que lhes permite, no limite, realizar mudanças estruturais que possam ampliar sua produtividade e competitividade internacional antes da adaptação a novas regras ou da liberalização comercial.

Na avaliação de representantes do setor privado consultados em nossa pesquisa, a participação nos comitês da Senalca e da Seneuropa funcionou bem, com transparência e integração do setor nas negociações, ainda que segundo a agenda da coordenação do Itamaraty. Em alguns casos, especialmente nas negociações da Alca e na OMC, os coordenadores da CEB tiveram acesso à sala de negociações como parte da delegação brasileira. Em outras, foram convidadas para estar no "quarto ao lado", de onde acompanhavam e discutiam com diplomatas aquilo que fora colocado na mesa na sala de negociação minutos antes. Assim, não obstante os problemas relativos ao condicionamento da interação segundo pautas definidas pelo governo, o setor empresarial fez bom 
uso das possibilidades de diálogo e de interação no intuito de defender seus interesses e preferências nas negociações comerciais em que o Brasil encontrou-se envolvido, particularmente Alca, Mercosul-UE e Rodada Doha. O Itamaraty, por outro lado, deu a suas ações maior legitimidade e referência às bases socioeconômicas e políticas do país.

OQuadro 1, a seguir, sintetiza os posicionamentos da CEB em cada um dos três trilhos da estratégia de negociação comercial do Brasil entre 1995 e 2010.

\section{Quadro 1}

Posicionamentos da CEB nos Três Trilhos da Estratégia de Negociação

Comercial do Brasil entre 1995 e 2010

\begin{tabular}{|l|l|}
\hline $\begin{array}{l}\text { Estratégia em } \\
\text { Três Trilhos }\end{array}$ & Posicionamentos da CEB \\
\hline $\begin{array}{l}\text { Negociações da } \\
\text { OMC }\end{array}$ & $\begin{array}{l}\text { Positivo, com muito interesse. Protege por mais tempo setores } \\
\text { pouco competitivos da indústria e gera ganhos aos setores mais } \\
\text { competitivos, fundamentalmente o agrícola. A CEB alerta, con- } \\
\text { tudo, para a necessidade de se manter tratamento diferenciado } \\
\text { aos países em desenvolvimento. A lógica defensiva (de parte da } \\
\text { indústria) e a ofensiva (do agronegócio, essencialmente) inte- } \\
\text { gram-se na dinâmica da negociação multilateral. }\end{array}$ \\
\hline $\begin{array}{l}\text { Ampliação da } \\
\text { integração } \\
\text { regional na } \\
\text { América do Sul }\end{array}$ & $\begin{array}{l}\text { Positivo. Os setores industriais têm interesses especiais na inte- } \\
\text { gração da América do Sul. Alguns dos setores mais fechados da } \\
\text { economia brasileira têm ganhado com o processo de integração } \\
\text { econômico-comercial na região. Como em geral a indústria bra- } \\
\text { sileira é a mais competitiva da América do Sul, a concorrência } \\
\text { nãoétemida. Destaca-se a importância de aprofundar acordos a } \\
\text { fim de que o Brasil não perca margem de preferência tarifária } \\
\text { com os acordos celebrados entre os países da região e outros de } \\
\text { fora dela, particularmente a China. }\end{array}$ \\
\hline $\begin{array}{l}\text { Negociação de } \\
\text { acordos } \\
\text { comerciais com } \\
\text { países de fora da } \\
\text { América do Sul }\end{array}$ & $\begin{array}{l}\text { Positivo e/ou negativo. Há setores que exigem proteção e não } \\
\text { desejam alguns acordos (como o setor de químicos o faz em rela- } \\
\text { çã à negociação de acordo comercial entre o Mercosul e o Con- } \\
\text { selho do Golfo, por exemplo). Nas negociações da Alca, alguns } \\
\text { setores industriais apresentaram posições ofensivas e outros } \\
\text { posições defensivas. Em geral, o setor agrícola é um dos mais in- } \\
\text { teressados na realização de um acordo entre o Mercosul e a UE. } \\
\text { Nesse trilho, a posição da CEB varia de acordo com o país como o } \\
\text { qual se negocia e com a agenda temática dessa negociação. } \\
\text { Pode-se afirmar, contudo, que a abertura relativamente rápida e } \\
\text { ampla que aos acordos regionais apresentam não é identificada, } \\
\text { em geral, pela CEB como preferencial. }\end{array}$ \\
\hline
\end{tabular}

Fonte: Documentos da CEB. Elaboração dos autores. 


\section{PREFERÊNCIAS E ATUAÇÃO DA REDE BRASILEIRA PELA INTEGRAÇÃO DOS POVOS}

Congregando organizações sindicais e ONGs, além de movimentos sociais, que tenham interesses relacionados ao processo de integração econômica e negociações comerciais, foi criada, em 1998, a Rebrip. A Rebrip trabalha pela construção de "uma sociedade democrática pautada em um desenvolvimento econômico, social, cultural, ético e ambientalmente sustentável" (Rebrip, 2001:1). A Rede define sua atuação na busca de alternativas à lógica da liberalização comercial e financeira que predomina nos acordos econômicos e comerciais nos dias de hoje. A contestação política se dá pela constituição de um grupo articulador de consensos e posições comuns aos seus membros, visando a apresentar alternativas e defender princípios e interesses sociais no campo das negociações comerciais. Assim, a atuação da Rebrip está vinculada à contestação da privatização de políticas e espaços públicos, como considerado por seus membros. Para Veiga (2007a):

A criação da REBRIP constitui uma inovação institucional, tal como constituiu, do lado empresarial, a criação da CEB. A REBRIP é uma rede de entidades de diferentes origens e objetivos que se dedica essencialmente a negociações comerciais - que não constitui o negócio principal de qualquer das entidades a ela filiadas - e cuja natureza multissetorial reflete a estrutura das agendas de negociações comerciais hoje. De acordo com um membro da REBRIP, isso assegura um acompanhamento mais adequado dos processos de negociação, possibilitando uma visão completa dos interesses em jogo e evitando a concentração num tema somente, que colocaria em risco o entendimento dos processos como um todo, as compensações envolvidas etc. (Veiga, 2007a:139, ênfase nossa).

Na avaliação da coordenadora da Rebrip, Fátima Mello: “A política externa brasileira sempre foi vista pelo grande empresariado industrial e do agronegócio como propriedade desses setores" (Mello, 2010:1). Daí, em sua visão, a importância da construção de uma rede de organizações sociais que ajude a pensar a política externa, e particularmente a política comercial externa, por novas perspectivas e auxilie no processo de democratização dessa política. Pois, como reitera Mello: “Ao longo dos últimos anos novas agendas e novos atores passaram a disputar os rumos da política externa, visando a democratizá-la e torná-la uma política pública que reflita os interesses múltiplos e conflitantes que existem na sociedade brasileira" (ibidem:1). 
Entre os temas centrais ao interesse da Rebrip encontram-se a agricultura, com enfoque de defesa do pequeno agricultor, os serviços, particularmente o que chamam de serviços sociais, o acesso a mercados para produtos não agrícolas, defendendo uma agenda de produção da indústria e do emprego no Brasil, o investimento e os direitos de propriedade intelectual, com foco na agenda de licenças compulsórias e quebra de patentes, e o meio ambiente, tema central na proposta do novo modelo de desenvolvimento sustentável defendido pela Rede. No que concerne à participação da Rebrip nos mecanismos oficiais de consultas e diálogo entre atores estatais e não estatais criados a partir das negociações da Alca, cabe salientar que a Rede teve atuação mais ativa na Senalca do que na Seneuropa ou mesmo no GICI, que tratava das negociações no âmbito da OMC. Ainda que igualmente condicionado pelos limites definidos pelo Itamaraty nos mecanismos de consulta, o posicionamento da Rebrip frente às negociações comerciais passou paulatinamente a incorporar elementos técnicos para a formatação de propostas concretas que pudessem ser levadas aos comitês.

Quando das negociações da Alca, a Rebrip foi convidada a levantar uma lista de produtos de interesse à agricultura de pequena escala que comporia as exceções à liberalização comercial negociada no acordo (Veiga, 2007b). O grau de abertura aos atores não estatais da sociedade civil organizada observada ao longo das negociações da Alca não foi encontrado nas negociações entre o Mercosul e a UE, muito mais fechado e pouco convidativo à participação ativa desses atores na Seneuropa. Com os fluxos de informações ampliados e a participação nos fóruns de consulta, a Rede inicia um processo de conhecimento da agenda de negociações comerciais internacionais que auxiliou na redefinição de suas estratégias de contestação política tanto dentro quanto fora dos mecanismos de participação e consultas à sociedade.

Em geral, a Rede mantém posicionamento crítico às negociações pelo Brasil de acordos comerciais regionais, particularmente com países do Norte. Para os movimentos e as organizações que compõem a Rebrip, a lógica liberal que impera na dinâmica de integração econômica que estrutura os mais diversos acordos comerciais estaria em desacordo com os interesses da sociedade em geral, pois traria custos elevados de adaptação à economia do país com prejuízos advindos da redução dos níveis de empregos e renda. A articulação da Rede contesta essa lógica, levando em conta a necessidade de se repensar o desenvolvimento nacional e regional em bases sociais e sustentáveis. 
Com base nesses princípios de contestação à ordem liberal vigente no quadro dos acordos comerciais, a Rebrip manteve posição defensiva e negativa quanto às negociações comerciais para a formação da Alca e do acordo entre o Mercosul e a União Europeia. Esse padrão de posicionamento negociador, que contesta as próprias premissas do modelo em vigor, também serviu para moldar as estratégias da Rede relacionadas aos demais acordos comerciais assinados com países em desenvolvimento nos últimos anos. Pode-se destacar essa posição em declaração da Rebrip (2007b) sobre as negociações entre o Mercosul e Israel para a formação de uma área de livre comércio. Como se afirma no documento:

Os movimentos sociais, organizações, redes e demais entidades vêm, por meio desta, se pronunciar ativamente contra a assinatura de um Tratado de Livre Comércio entre o MERCOSUL e o Estado de Israel. Pelas mesmas razões que nos opusemos à ALCA e aos tratados de livre comércio entre Europa e MERCOSUL, denunciamos hoje este acordo que estabelece "a criação de uma Área de Livre Comércio" entre os cinco países mencionados, assim como o compromisso "com os princípios da Organização Mundial de Comércio (OMC)” (Rebrip, 2007b:1).

Em documento intitulado "Propostas para a Política Externa do Brasil", a Rebrip afirma a necessidade de se construir uma agenda que leve a outro modelo de desenvolvimento. Para alcançar essa meta, a PEB deveria trabalhar para democratizar o sistema internacional, com vista à ampliação de agenda e à democratização de organismos multilaterais, econômicos e políticos, além da redução de assimetrias econômicas e de poder. De acordo com a Rebrip (2010), a construção de um novo multilateralismo, democrático e inclusivo, que vai além do ator estatal em seus processos de participação, deveria ser prioridade na agenda de política externa do Brasil:

O Brasil deve apostar na transição para um novo multilateralismo, que expresse uma nova agenda e uma nova correlação de forças. Ao invés de ser ordenada de acordo com os interesses militares, financeiros e comerciais das grandes potências e corporações, um novo multilateralismo democrático deveria priorizar o enfrentamento da transição a um novo modelo de desenvolvimento, das imensas desigualdades entre Norte e Sul, mas também no interior dos países, da garantia dos direitos, da construção de soluções reais para as mudanças climáticas e outros conflitos socioambientais. Neste novo multilateralismo as finanças e o comércio estariam submetidos ao atendimento 
dos direitos e da transição a um novo modelo de desenvolvimento (Rebrip, 2010:1, ênfases nossas).

A agenda de reformas propostas para o multilateralismo pela Rebrip dá o tom da crítica da instituição acerca dos princípios que estruturam os acordos comerciais existentes e administrados sob os auspícios da OMC. Segundo a visão preponderante na Rede, as negociações no âmbito do regime multilateral de comércio ganharam força e tiveram sua agenda ampliada e aprofundada desde a Rodada Uruguai em consonância com os interesses de importantes empresas transnacionais, grandes vencedoras no modelo liberal de acordos, segundo a Rede. Para a Rebrip (2008):

Desde a sua criação em 1995, o objetivo da OMC é a crescente liberalização do comércio agrícola, de serviços, de investimentos, beneficiando assim as grandes corporações que visam expandir seus lucros no mundo, e para isso precisam de um ambiente livre de regulações, de leis nacionais e de políticas públicas. As grandes corporações sempre foram as maiores beneficiadas pelas regras da OMC, que removem os mecanismos que consideram discriminatórios adotados por alguns países para defenderem sua indústria e sua agricultura (Rebrip, 2008c:2, ênfase nossa).

Quando do lançamento do Pacote de Julho de 2008, a principal tentativa de conclusão da Rodada Doha, na qual a diplomacia brasileira envidou esforços importantes, a Rebrip apresentou documento público no qual contesta os termos do Pacote e demanda ao governo brasileiro a paralisação das negociações multilaterais. Na visão da Rebrip, se concluída, Doha poderá significar a ampliação do desgaste do meio ambiente no Brasil com prejuízos sociais importantes vinculados à suposta desindustrialização pela qual a economia do país poderia passar. Assim, articulando elementos ambientais, sociais e econômicos em seu discurso contra a conclusão da Rodada Doha, a Rede:

(...) demanda que o Governo Brasileiro pare de negociar nestes termos. Não haverá um mercado socialmente justo se a Rodada de Doha for concluída em prejuízo dos setores produtivos mais vulneráveis. Os desequilíbrios e assimetrias resultantes deste acordo levariam o Brasil e muitos outros países do Sul à desindustrialização, a uma ainda maior falta de segurança e soberania alimentar, ao avanço dos monocultivos voltados à exportação, a um aprofundamento da privatização de serviços, à perda de empregos e limitações para o atendimento na prestação de serviços à população. (...) Esta dinâmica das negociações estimula o aprofundamento de um mo- 
delo baseado na exportação de produtos agrícolas primários, de baixo valor agregado, que exigem o uso intensivo de energia, de água e de insumos químicos na sua produção e de vastas extensões de terras para a pecuária e os monocultivos, que aumentam a concentração fundiária e os desmatamentos, e empobrecem a biodiversidade e a agrobiodiversidade (Rebrip, 2008b:1-3, ênfases nossas).

Na contestação das negociações comerciais multilaterais, a REBRIP levantou argumentos relacionados à própria política de aproximação do governo Lula com países em desenvolvimento na formação de coalizões e arranjos negociadores. Para a Rede, países parceiros como Argentina e Índia estariam buscando resistir ao processo liberalizador que embasa as negociações na OMC. Nesse sentido, a Rebrip (2008) afirmou que:

(...) não podemos aceitar que a Rodada de Doha seja concluída nas bases propostas, pois isto significaria um retrocesso em relação às conquistas obtidas em nossas lutas de resistência. Significaria um distanciamento do Brasil da construção de alianças estratégicas com países como Argentina e Índia que têm tentado resistir no processo negociador da OMC. Também significaria um bloqueio ao processo de integração regional em curso, pois este requer preferências e prioridades para o desenvolvimento para dentro de nossa região, ao invés de destinarmos nossas estruturas produtivas à exportação para os países do Norte. Por estes motivos, dizemos Não a Rodada de Doha da OMC e conclamamos a sociedade brasileira a debater e resistir (Rebrip, 2008a:4, ênfase nossa).

Diferentemente de sua participação na Senalca, a atuação da Rebrip no GICI sobre as negociações comerciais multilaterais foi marginal, quase inexistente. Na maioria das vezes, a Rede não foi convidada a participar das reuniões de consultas, que se limitaram fundamentalmente ao setor privado articulado na CEB. Com isso, a Rebrip tomava ciência das negociações em curso na Rodada Doha por meio do acompanhamento da agenda disponibilizada pela própria OMC. Desde então, a Rede reforçou seu posicionamento crítico sobre a importância da transparência da participação brasileira nas negociações internacionais e a necessidade de consultas sistemáticas tanto aos setores empresariais quanto aos sindicais e sociais sobre essas negociações. Em carta ao Ministro das Relações Exteriores, Celso Amorim, em 2007, a Rebrip critica a falta de transparência e a alegada precipitação do Brasil quanto às negociações multilaterais na Rodada Doha: "Vimos por meio desta mais uma vez manifestar nossa extrema preocupação com a falta de trans- 
parência, o conteúdo e a precipitação e com a qual se tenta chegar a uma conclusão da Rodada Doha de negociações na OMC" (Rebrip, 2007a:1, ênfase nossa).

Essa falta de transparência não seria encontrada no âmbito da integração regional, tendo o Mercosul como base. Dentre as propostas da Rebrip (2010) para repensar a política externa do Brasil, a Rede destaca a importância de fortalecer a cooperação e a integração regional na América do Sul. Assim, dos três trilhos da estratégia de negociação comercial do Brasil estruturada entre 1995 e 2010 apenas o da ampliação da rede de acordos regionais na América do Sul encontra apoio, ainda que condicionado e relativo, nos posicionamentos políticos da Rebrip no campo das negociações comerciais internacionais. O apoio é condicionado e relativo porque, embora reconheça a importância da agenda da integração regional, a Rebrip considera a necessidade de se seguir no processo por meio da ampliação da agenda social e ambiental dos acordos existentes.

A Rede identifica na integração produtiva elementos capitais que permitem aos países da América do Sul lidar com as assimetrias econômicas e projetar uma agenda positiva no campo do emprego e da renda no âmbito regional. Os acordos comerciais com os países da região são tolerados quando vistos no quadro do processo de integração mais amplo. Algumas das ações realizadas ao longo do governo Lula no campo da integração regional, como a criação do Focem e do Parlasul e a inserção de uma agenda social no processo, coadunam-se com interesses e preferências observadas nos posicionamentos da Rede sobre a ampliação da integração regional na América do Sul. Como afirma a Rebrip (2010):

O Brasil deve seguir tomando iniciativas que indiquem um investimento político no fortalecimento da coordenação e concerto regional na América Latina, fortalecendo o processo de integração regional consolidando o MERCOSUL e construindo a UNASUL - e priorizando uma agenda que tenha como objetivos centrais o desenvolvimento sustentável. No processo de consolidação do MERCOSUL, o governo brasileiro deve contribuir para superar as disparidades e assimetrias entre nossa economia e a dos demais países parceiros, através de um forte programa de integração produtiva, com foco na articulação de suas cadeias produtivas, processo que deve ter como objetivo central a distribuição dos ganhos em toda a cadeia produtiva, a geração de empregos decentes e a garantia que a especialização produtiva em cada país não se consolide à custa da redução dos direitos traba- 
Ihistas e efeitos predatórios sobre o meio ambiente, incentivando o desenvolvimento tecnológico, social e sustentável de forma igualitária entre os países membros do MERCOSUL (Rebrip, 2010:1, ênfases nossas).

Tomando por base o quadro de preferências que pautou a atuação da Rebrip desde a sua criação em 1998, é importante frisar que, como toda organização social, a Rede abrange um leque multivariado de interesses e posições entre seus membros. A dinâmica política da disputa interna leva à construção de pontos de consenso que são defendidos pela Rede, estruturados fundamentalmente no princípio que norteia a própria lógica de atuação de cada uma das organizações e movimentos que a compõem, qual seja: a contestação da ótica liberal nas negociações comerciais internacionais e a denúncia do modelo capitalista vigente. Sobre as distintas posições existentes entre os membros da Rebrip, Veiga (2007a) afirma:

Há, na realidade, uma grande variedade de posições e pontos de vista políticos na Rede. De acordo com um funcionário responsável pela área de relações internacionais de uma importante ONG brasileira, uma cisão coloca "soberanistas" - que defendem que o país deva preservar espaços para políticas públicas - em oposição àqueles que aceitam algum desgaste da soberania em benefício de projetos de integração, especialmente na América do Sul. Outra cisão coloca "institucionalistas" - favoráveis ao multilateralismo e ao aperfeiçoamento da OMC - contra "movimentistas" , contrários à globalização e à OMC (Veiga, 2007a:141-142).

A lógica antiliberal que fundamentou a atuação da Rede dentro e fora dos mecanismos de consulta e participação da sociedade instituídos pelo Itamaraty ressalta a importância de se colocarem os "interesses sociais" à frente dos "interesses comerciais" quando das negociações de acordos econômicos pelo Brasil. Nesse sentido, a manutenção de espaços para política pública em todas as áreas de atuação do Estado é apresentada como elemento essencial a ser preservado em qualquer acordo. Assim, a vontade política socialmente construída no ambiente doméstico não deve ser sobreposta por interesses e regras internacionais. Essa visão é bem sintetizada no seguinte excerto de documento publicado pela Rede:

No âmbito da política de comércio exterior, é fundamental garantir que, em todos os processos em que o Brasil esteja envolvido, OS INTERESSES SOCIAIS PREVALEÇAM SOBRE OS INTERESSES MERAMENTE COMERCIAIS, resguardando mecanismos de proteção tarifária para a produção e o desenvolvimento nacional, a possibili- 
dade de que o avanço científico e tecnológico seja usado em prol do conjunto da humanidade, particularmente os grupos mais fragilizados, e não com o fim precípuo do lucro, que acordos internacionais não devem se sobrepor a regulamentações nacionais, que os direitos do consumidor sejam garantidos e que o acesso a serviços de boa qualidade sejam universais (Rebrip, 2010:2, ênfases nossas).

O Quadro 2, a seguir, resume os posicionamentos da Rebrip em cada um dos três trilhos da estratégia de negociação comercial do Brasil entre 1995 e 2010.

\section{Quadro 2}

Posicionamentos da Rebrip nos Três Trilhos da Estratégia de Negociação

Comercial do Brasil entre 1995 e 2010

\begin{tabular}{|l|l|}
\hline $\begin{array}{l}\text { Estratégia em } \\
\text { três trilhos }\end{array}$ & Posicionamentos da Rebrip \\
\hline $\begin{array}{l}\text { Negociações da } \\
\text { na OMC Doha }\end{array}$ & $\begin{array}{l}\text { Negativo. A Rebrip considera que o enfoque agrícola da Agenda } \\
\text { do Desenvolvimento da Rodada Doha e o empenho brasileiro na } \\
\text { defesa dessa agenda atendem a interesses meramente comerciais. } \\
\text { Para a Rede as negociações sobre serviços são tratadas segundo } \\
\text { interesses das grandes empresas transnacionais. Na visão da Re- } \\
\text { brip, haveria perdas para múltiplos setores sociais caso um acor- } \\
\text { do final fosse fechado na OMC. A Rebrip condena, pois, toda lógi- } \\
\text { ca econômica e política que sustenta as negociações em âmbito } \\
\text { multilateral. }\end{array}$ \\
\hline $\begin{array}{l}\text { Ampliação da } \\
\text { integração } \\
\text { regional na } \\
\text { América do Sul }\end{array}$ & $\begin{array}{l}\text { Positivo, mas com o imperativo de ampliar o enfoque social e de- } \\
\text { senvolvimentista. A Rebrip defende o fortalecimento da integra- } \\
\text { ção regional com objetivos vinculados ao desenvolvimento sus- } \\
\text { tentável, superando assimetrias econômicas entre os países por } \\
\text { meio de integração produtiva que gere empregos, proteção do } \\
\text { meio ambiente e desenvolvimento tecnológico de forma igualitá- } \\
\text { ria na região. A Rede destaca a necessidade de se manterem meca- } \\
\text { nismos de proteção tarifária que auxiliem aos países da região a } \\
\text { fazer uso de política comercial para defender empregos em suas } \\
\text { economias. }\end{array}$ \\
\hline $\begin{array}{l}\text { Negociação de } \\
\text { acordos } \\
\text { comerciais com } \\
\text { países de fora } \\
\text { da América do }\end{array}$ & $\begin{array}{l}\text { Negativo. Tanto as negociações da Alca quanto as do acordo entre } \\
\text { Mercosul e a UE ganharam forte oposição da Rebrip, tendo a pri- } \\
\text { meira um status diferenciado na lógica de contestação política fei- } \\
\text { ta pela Rede. O acordo com Israel foi condenado tanto por ques- } \\
\text { tões de ideologia política quanto econômica. Apenas os acordos } \\
\text { preferenciais com escopo muito reduzido negociados com países } \\
\text { em desenvolvimento, particularmente com países considerados } \\
\text { aliados, como a Índia, ganharam algum tipo e menção relativa- } \\
\text { mente positiva, mas com reservas, pela Rebrip. }\end{array}$ \\
\hline
\end{tabular}

Fonte: Documentos da Rebrip. Elaboração dos autores. 


\section{CONSIDERAÇÕES FINAIS: ENTRE CONVERGÊNCIA E CONTESTAÇÃO}

Este artigo buscou analisar como os atores empresariais, articulados em torno da CEB, e organizações e redes da sociedade civil, por meio da Rebrip, atuaram na defesa de seus interesses com vistas a influenciar, entre meados dos anos 1990 e o final do governo Lula, a formulação das estratégias de negociação comercial do Brasil. Também procurou compreender em que medida essa atuação foi importante para a definição de prioridades negociadoras, ou seja, a recepção pelas instituições políticas dessa expressão de interesses.

Considerando-se a projeção dos interesses coordenados pela CEB na agenda de formulação da política comercial externa do Brasil, pode-se afirmar que houve convergência com os interesses dos atores estatais envolvidos no que concerne à escolha dos fóruns de negociação comercial. Destacou-se, contudo, o perfil eminentemente protecionista dos interesses coordenados pela CEB nas principais negociações de acordos regionais e multilaterais em que o Brasil esteve envolvido no período em análise. Embora posições ofensivas relacionadas à lógica de abertura comercial internacional tenham surgido em determinados setores econômicos participantes da CEB, especialmente no campo agrícola, ainda são importantes (e, em geral, protagonistas) as posições defensivas da Coalizão nas negociações comerciais, que favorecem particularmente alguns setores industriais e de serviços no Brasil.

A prioridade conferida na estratégia de política comercial externa do Brasil entre 1995 e 2010 às negociações multilaterais de comércio e à ampliação da integração regional na América do Sul por meio de acordos comerciais coadunou-se com as preferências negociadoras da CEB, que tem múltiplos interesses setoriais atendidos com as negociações multilaterais na Rodada Doha e vê o espaço de integração ampliada no continente sul-americano como relevante para o incremento de exportações e ganhos de competitividade internacional. Nas principais negociações de acordos regionais com países de fora da América do Sul, observou-se um perfil eminentemente protecionista dos interesses coordenados pela CEB.

Ao se considerarem as preferências e a atuação da Rebrip nos três trilhos de negociação comercial seguidos pela política comercial externa do Brasil nas últimas décadas, pode-se afirmar que o papel da Rede estruturou-se essencialmente no campo da contestação dos princípios da própria estratégia negociadora, sendo marginal seu aporte direto na 
formatação da agenda de negociação dos acordos comerciais tanto em nível regional quanto multilateral. Como se analisou, a Rebrip apresentou posição defensiva e negativa quanto aos acordos regionais negociados pelo Brasil com países de fora da América do Sul e também em relação às negociações de acordos multilaterais na Rodada Doha, considerados prejudiciais à economia, ao desenvolvimento social e à proteção dos interesses do meio ambiente nos planos nacional e regional. Apenas no que concerne à integração regional encontram-se aspectos de avaliação positiva da Rede, mas ainda assim com ressalvas, em relação às estratégias de política comercial adotadas pelo Brasil, particularmente no período entre 2003 e 2010.

De toda forma, a participação da Rebrip enquanto coordenador de interesses da sociedade civil organizada no debate sobre a inserção internacional brasileira é importante como elemento da democratização da agenda de política externa em geral, e de política comercial externa em particular. O interesse da sociedade em assuntos internacionais é ainda muito recente no Brasil e a consolidação da Rede como ator nas discussões sobre comércio e negociações internacionais auxilia na reflexão necessária sobre os impactos da ação internacional do Brasil sobre a sociedade brasileira e a economia doméstica. Demonstra, ademais, que o foco dos interesses das redes e dos movimentos sociais pode ir além dos temas tradicionais, tais como direitos humanos, cooperação para o desenvolvimento, bens culturais e educação, e voltar-se a temas da agenda prioritária de negociação da PEB (integração regional, acordos comerciais, segurança, entre outros). É evidente que o desafio também se coloca para redes e movimentos da sociedade civil brasileira no sentido de se formarem em temas bastante especializados de política internacional e política externa, mas igualmente de despertarem o interesse da opinião pública por assuntos dessa natureza, processo que poderia, prospectivamente, contribuir para a ampliação quantitativa e qualitativa das constituencies ${ }^{3}$ dessa política pública sui generis que é a política externa brasileira.

(Recebido para publicação em janeiro de 2012)

(Reapresentado em março de 2012)

(Aprovado para publicação em maio de 2012) 


\section{NOTAS}

1. Como lembra Souza (2006:24), "não existe uma única, nem melhor, definição sobre o que seja política pública". Aqui adotamos a definição de política pública como o conjunto das atividades do governo que, agindo direta ou indiretamente (por exemplo, por delegação ou pela ação de agentes não governamentais), acaba por influenciar o cotidiano dos cidadãos. Tais ações do governo se inspiram em um modelo institucional e em uma tradição histórica de Estado.

2. Segundo o artigo $4^{\underline{O}}$ do Título I da Constituição, os princípios são os seguintes: I) independência nacional; II) prevalência dos direitos humanos; III) autodeterminação dos povos; IV) não intervenção; V) igualdade entre os Estados; VI) defesa da paz; VII) solução pacífica dos conflitos; VIII) repúdio ao terrorismo e ao racismo; IX) cooperação entre os povos para o progresso da humanidade; X) concessão de asilo político. Parágrafo único: a República Federativa do Brasil buscará a integração econômica, política, social e cultural dos povos da América Latina, visando à formação de uma comunidade latino-americana de nações.

3. No mundo anglo-saxão, o termo constituency remete a qualquer grupo coeso de indivíduos ligados por identidades compartilhadas, laços culturais, valores, interesses e lealdades comuns. O termo pode ser usado para descrever um conjunto de eleitores, apoiadores de uma fundação, clientes ou acionistas de uma empresa, bem como por extensão os atores envolvidos e interessados por determinados temas e agendas de políticas públicas (Bogdanor, 1985).

\section{REFERÊNCIAS BIBLIOGRÁFICAS}

ABREU, Marcelo de Paiva. (2007), Comércio Exterior: Interesses do Brasil. Rio de Janeiro, Elsevier.

AMORIM, Celso. (2010), Entrevista. Revista Desafios do Desenvolvimento, no61, pp.10-21.

AMORIM NETO, Octavio. (2011), De Dutra a Lula , a Condução e os Determinantes da Política Externa Brasileira. Rio de Janeiro, Elsevier.

BADIE, Bertrand. (2010), O Diplomata e o Intruso: A Entrada das Sociedades na Arena Internacional. Salvador, EdUFBA.

BOGDANOR, Vernon. (1985), Representatives of People? Parliamentarians and Constituents in Western Democracies. Aldershot, Gower.

BRASIL. Ministério das Relações Exteriores. Secretaria de Planejamento Diplomático. (2007), Repertório de Política Externa: Posições do Brasil. Brasília, Fundação Alexandre de Gusmão. 
CAPLING, Ann e LOW, Patrick. (2010), Governments, Non-State Actors and Trade Policy-making: Negotiating Preferentially or Multilaterally? New York, Cambridge University Press.

CARVALHO, Maria Isabel V. de. (2010), “Condicionantes Internacionais e Domésticos: O Brasil e o G-20 nas Negociações Agrícolas da Rodada Doha". Dados, vol. 53, no 2, pp. 405-445.

. (2003), “Estruturas Domésticas e Grupos de Interesse: A Formação da Posição Brasileira para Seattle". Contexto Internacional, vol. 25, no 2, pp. 363-401.

CEB (COALIZÃO EMPRESARIAL BRASILEIRA). (2005), Towards a Successful Round: CEB's Objectives in the Main Areas. Disponível em http:/ / www.negociacoesinternacionais.cni.org.br. Acessado em 10/4/2011.

. (2004), Subsídios para a Formação da Posição Negociadora Brasileira na Continuação da XVII Reunião do Comitê de Negociações Comerciais (CNC) da ALCA. Disponível em http:/ / www.negociacoesinternacionais.cni.org.br. Acessado em 10/4/2011.

(2002), Madrid Declaration. Mercosur/European Union Business Forum. Disponível em http:/ / www.negociacoesinternacionais.cni.org.br. Acessado em 10/4/2011.

. (2001), OMC: Documento sobre o Lançamento de uma Nova Rodada de Negociações Multilaterais. Disponível em http:/ / www.negociacoesinternacionais.cni.org.br. Acessado em 10/4/2011.

. (1999), Os Empresários Brasileiros e a Rodada do Milênio: Contribuições da Coalizão Empresarial Brasileira. Disponível em http://www.negociacoesinternacionais.cni. org.br. Acessado em 10/4/2011.

. (1997), ALCA - Área de Livre Comércio das Américas: Documento de Posição Empresarial Brasileira. Disponível em http://www.negociacoesinternacionais.cni.org.br. Acessado em 10/4/2011.

GALLAGNER, Peter, LOW, Patrick e STOLER, Andrew. (2006), Managing the Challenges of WTO Participation. New York, Cambridge University Press.

HOCKING, Brian. (2004), “Changing the Terms of Trade Policy-making: From the Club to the Multistakeholder Model". World Trade Review. vol. 3, no 1, pp. 3-26.

INTAL (INSTITUTO PARA A INTEGRAÇÃO DA AMÉRICA LATINA E CARIBE). (2002), "The Trade Policy-Making Process: Level One of the Two Level Game: Country Studies in the Western Hemisphere". Occasional Paper 13. Buenos Aires, BID-Intal.

LAFER, Celso. (2007), “Novas Variações sobre a Política Externa”. Estado de S. Paulo, 16/12/2007. Disponível em http://www.estado.com.br/editorias/2007/12/16/ opi-1.93.29.20071216.1.1.xml. Acessado em 10/11/2011.

LIMA, Maria Regina Soares de. (2005), “Aspiração Internacional e Política Externa”. Revista Brasileira de Comércio Exterior, vol. 19, no 82, pp. 4-19.

. (2000), “Instituições Democráticas e Política Exterior". Contexto Internacional, vol. 22, no 2, pp.265-303.

. (1990), “A Economia Política da Política Externa Brasileira: Uma Proposta de Análise". Contexto Internacional, vol. 12, pp. 7-27. 
e SANTOS, Fabiano. (2001), “O Congresso e a Política de Comércio Exterior”. Lua Nova, no 52, pp. 121-149.

LOPES, Dawisson Belém. (2011), “A Política Externa Brasileira e a 'Circunstância Democrática': Do Silêncio Respeitoso à Politização Ruidosa". Revista Brasileira de Política Internacional, vol. 54, no 1, pp. 67-86.

MELLO, Fátima. (2010), “Diplomacia Democrática”. O Globo. Opinião, 8/9/2010. Disponível em http:/ / www.rebrip.org.br. Acessado em 10/5/2011.

MILANI, Carlos R. S. (2012), "Atores e Agendas no Campo da Política Externa Brasileira de Direitos Humanos", in L. Pinheiro e C. R. S. Milani (orgs.), Política Externa Brasileira: As Práticas da Política e a Política das Práticas. Rio de Janeiro, FGV Editora.

MOURA, Cristina Patriota. (2007), O Instituto Rio Branco e a Diplomacia Brasileira. Rio de Janeiro, FGV Editora.

OLIVEIRA, Amâncio Jorge, ONUKI, Janina e VEIGA, J. P. C. (2006), “Política externa e negociações internacionais". Revista Brasileira de Comércio Exterior, vol. XX, pp. 29-33.

PINHEIRO, Letícia. (2009), “Autores y Actores de la Política Exterior Brasileña”. Foreign Affairs Latinoamérica, vol. 9, no 2, pp.14-24.

e MILANI, Carlos R. S. (orgs.), (2012), Política Externa Brasileira: As Práticas da Política e a Política das Práticas. Rio de Janeiro, FGV Editora.

REBRIP (REDE BRASILEIRA PELA INTEGRAÇÃO DOS POVOS). (2010), Propostas para a Política Externa do Brasil. Rio de Janeiro. Disponível em http://www.rebrip.org.br. Acessado em 10/5/2011.

(2008a), "Por que Dizer Não à Rodada de Doha da OMC". Disponível em http:/ /www.rebrip.org.br. Acessado em 10/5/2011.

. (2008b), “Riscos para Setor de Serviços na OMC: Carta ao Excelentíssimo Sr. Ministro das Relações Exteriores Celso Amorim". Disponível em http://www.rebrip.org.br. Acessado em 10/5/2011.

. (2008c), "Movimentos Sociais Comemoram mais um Fracasso da Rodada de Doha da OMC". Disponível em http:/ /www.rebrip.org.br. Acessado em 10/5/2011.

(2007a), “Carta ao Ministro Amorim sobre Rodada Doha”. Disponível em http:/ / www.rebrip.org.br. Acesso em 10/5/2011.

. (2007b), Declaração: NÃO ao TLC entre o Mercosul e o Estado de Israel. Rio de Janeiro. Disponível em http://www.rebrip.org.br. Acessado em 10/5/2011.

. (2001), I Assembleia Geral da Rebrip. Disponível em http://www.rebrip.org.br. Acessado em 10/5/2011.

SANCHEZ BADIN, Michele R. e FRANÇA, Cassio. (2010), A Inserção Internacional do Poder Executivo Federal Brasileiro. São Paulo, Fundação Friedrich Ebert.

SANTANA, Helton R. P. (2001), “Grupos de Interesse e a Política Externa Brasileira para a ALCA". Contexto Internacional, vol. 23, no 1, pp.167-196.

SOUZA, Celina. (2006), “Políticas Públicas: Uma Revisão da Literatura”. Sociologias, ano 8, no 16, pp. 20-45. 
VEIGA, Pedro da Motta. (2007a), “Política Comercial no Brasil: Características, Condicionantes Domésticos e Policy-Making", in M. S. Jank e S. D. Silber (orgs.), Políticas Comerciais Comparadas: Desempenho e Modelos Organizacionais. São Paulo, Singular, pp. 71-162.

. (2007b), “Trade Policy-Making in Brazil: Changing Patterns in State-Civil Society Relationship", in M. Halle e R. Wolfe (eds.), Process Matters: Sustainable Development and Domestic Trade Transparency. Winnipeg, International Institute for Sustainable Development, pp. 143-182.

. (2002), "Trade Policy-Making in Brazil: Transition Paths", in INTAL-ITD-STA, Trade Policy-Making Process Level One of the Two Level Game: Country Studies in the Western Hemisphere. Buenos Aires, Intal-ITD-STA, pp.13-21.

WOLFE, Robert e HELMER, Jesse. (2007), “Trade Policy Begins at Home: Information and Consultation in the Trade Policy Process", in M. Halle e R. Wolfe (eds.), Process Matters: Sustainable Development and Domestic Trade Transparency. Winnipeg, International Institute for Sustainable Development, pp. 1-19. 


\section{ABSTRACT \\ Non-State Actors and Trade Policy-Making in Brazil: An Analysis of Interests and Strategies in CEB and REBRIP}

The article analyzes how actors from the business sector (CEB) and organized civil society (REBRIP) worked to defend their interests in order to influence Brazil's international trade negotiation strategy-making between 1995 and 2010. The study also seeks to understand the extent to which non-state actors succeeded in affecting the Brazilian government's definition of its official positions and priorities. The main conclusions are the following: a) a convergence of interests between business sectors and institutional actors vis-à-vis the choice of trade negotiation forums; b) the essentially protectionist profile of interests coordinated by CEB in the main negotiations; c) the role of REBRIP, organized primarily in the field of challenging the principles of the negotiating strategy itself, with only a marginal direct contribution to shaping the agenda for negotiating regional or multilateral trade agreements; and d) the involvement of REBRIP as an element for democratization of the foreign trade policy agenda in Brazil.

Key words: Brazilian foreign policy; trade negotiations; non-state actors; decision-making process

\section{RÉSUMÉ}

Acteurs non institutionnels et Trade Policy-Making au Brésil: analyse des intérêts et des stratégies de la CEB et de la REBRIP

Dans cet article, on examine comment des acteurs du monde des entreprises (CEB) et de la société civile organisée (REBRIP) ont cherché à défendre leurs intérêts afin d'influencer, entre 1995 et 2010, la mise em oeuvre des stratégies internationales de négociation commerciale au Brésil. On cherche aussi à comprendre dans quelle mesure le travail d'acteurs non institutionnels a réussi à produire des effets dans la définition de choix et de priorités officielles du gouvernement brésilien. En conclusion, on souligne: a) la convergence d'intérêts entre secteurs des entreprises et acteurs institutionnels en ce qui concerne le choix des forums de négociation commerciale; b) le profil plutôt protectionniste des intérêts coordonnés par la CEB dans les négociations les plus importantes; c) le rôle de la REBRIP fondé essentiellement sur la contestation des principes de la stratégie de négociation, rendant ainsi marginal son apport direct dans le calendrier de négociations des accords commerciaux, aussi bien au niveau régional que multilatéral; d) l'engagement de la REBRIP considéré comme un facteur de démocratisation de l'ordre du jour de la politique étrangère du Brésil en matière de commerce.

Mots-clés: politique étrangère brésilienne; négociations commerciales; acteurs non institutionnels; prise de décision 